\title{
The Role of Motivation in Mediating the Effect of Competence and Leadership on Employee Performance in Outpatient Poly Installation of Wing Amerta RSUP Sanglah Denpasar
}

\author{
Eka Suardika \\ Universitas Warmadewa, Denpasar, Bali-Indonesia \\ ekasuardika51@yahoo.com
}

\begin{tabular}{|l|}
\hline \\
\hline How to cite (in APA style): \\
Suardika, Eka. (2020). The Role of Motivation in Mediating the Effect of Competence and Leadership on Employee \\
Performance in Outpatient Poly Installation of Wing Amerta RSUP Sanglah Denpasar. Jurnal Ekonomi dan Bisnis \\
Jagaditha, 7(2), 73-79. doi: https://doi.org/10.22225/jj.7.2.1962.1-7
\end{tabular}

\begin{abstract}
Performance is the performance of work or output (output) both quality and quantity. The purpose of this study is to analyze the role of motivation in mediating the influence of competence and leadership on the employee performance of Wing Amerta Installation Sanglah Denpasar Hospital, the respondents are all 50 outpatient personnel, the data collected related to competence, leadership, motivation and performance. The data was analysed by using PLS (Partial Least Square). The results of this research has positive and significant influence on motivation, leadership has positive influence on motivation and significance, positive competence to performance, and the relationship is significant, competence has positive effect on motivation and relationship is significant, motivation has positive effect on performance and relationship is significant, motivation is partial mediation between Competence to performance, and motivation is the perfect mediation between Leadership on performance.
\end{abstract}

Keywords: Competence; Leadership; Motivation; and Performance

\section{INTRODUCTION}

Basically, employee performance is individual ability because each employee has a different level of ability to complete the work. Robbins \& Judge (2013) stated that performance can be measured by productivity, turnover, citizenship and satisfaction. A person's performance depends on a combination of ability, effort and opportunity obtained. Employee performance is the result or level of overall success of a person during a certain period in carrying out the task compared to the standard of work, targets or targets or criteria that have been determined in advance and have been mutually agreed upon (Rivai, 2013). In addition, (Mathis \& Jackson, 2006) revealed that performance employees are measured by, quantity, quality, timeliness, attendance at work, efficiency in completing work, effectiveness in completing work.

There some factors that determine performance namely job competency, work environment, job satisfaction (Dharmanegara,
Sitiari, \& Wirayudha, 2016) also motivation to have a significant and positive effect on employee performance. Morover, (Tarandung, 2016) based on previous research employee performance is determined by competence, motivation, work environment, which is more researched in public organizations, (Rai \& Purnawati, 2017) in his research states that different results of leadership have a negative and not significant effect on performance, and retirees find leadership has no effect on employee performance so it needs to be reexamined in different organizations by adding variable motivation and competence.

Motivation plays a role in improving employee performance because it is a result of one's interaction with certain situations faced. Motivation is the willingness to spend a high level of effort for organizational goals that are conditioned by the ability of the effort to meet some individual needs (Robbins \& Judge, 2013). Indicators of motivation according to 
McClellend's describes three types of motivation, which are identified in the book "The Achieving, (achievement motivation), (motivational power), (affiliated motivation). In Mc.Lelland's tiori achievement motivation needs for achievement is the drive to surpass, achievement in connection with a set of standards, wrestle for success, individual characteristics that show high orientation include being willing to accept relatively high risks, the desire to get feedback about work results they are, desires to get the responsibility of solving problems. Motivation in power according to Mc.Lelland's need for others to behave in a way where those people without being forced will not behave in this way or a form of expression from individuals to control and influence others, while, affiliation motivation is the desire to connect between friendly and intimate personalities, individuals reflect the desire to have close, cooperative and friendly relationships with others, individuals who have high affiliation needs generally succeed in jobs that require high social interaction. Mc.Lelland's said that most people have a combination of these characteristics, as a result will affect the behavior of employees in working or managing the organization. Motivational research on employee performance is significant and positive (Kardiasih, Yasa, \& Sitiari, 2017), but besides motivation, performance is also determined by competence.

Employee competency is a characteristic that is owned by each individual to meet certain criteria or positions. The more competent an employee better they are more responsible and professional to produce better performance. each employee must have five characteristics including: (1) Motives, (2) Innate factors, (3) Self-concept, (4) Knowledge and (5) Skills. To develop these competencies, employees must have a good attitude towards their profession. Attitudes are always about both good and negative objects. This is reinforced by the opinion of (Walgito, 2003) that a professional conducts his work in accordance with the demands of the profession. Research with variable influence of competence on performance that is significant and positive
(Ginantra, 2017) which states leadership has a positive influence on employee performance. Furthermore, (Ardana, 2012) expressed that leadership is the overall activity in order to influence people to want to work together to achieve an organization's desired goals together.

The purpose of this study is to analyze and explain the effect of competence on employee motivation in the Amerta Wing Hospital in Denpasar Sanglah Hospital. To analyze and explain the influence of leadership on employee motivation in the Amlah Wing Hospital in Denpasar. To analyze and explain the effect of competency on employee performance in the Wing Amerta Installation of Sanglah Hospital Denpasar. To analyze and explain the influence of leadership on employee performance at the Wing Amerta Installation of Sanglah General Hospital, Denpasar. To analyze and explain the effect of motivation on employee performance at the Wing Amerta Installation at Sanglah Hospital Denpasar. To analyze and explain the role of motivation in mediating the effect of competence on employee performance at the Wing Amerta Installation of Sanglah Hospital, Denpasar. To analyze and explain the role of motivation in mediating the influence of leadership on employee performance at the Wing Amerta Installation of Sanglah Hospital Denpasar.

Based on the above problems, the study of the role of motivation in mediating the effect of competence, leadership on the performance of outpatient staff at Wing Amerta, RSUP Sanglah, Denpasar. To analyze how much influence the competence, leadership and motivation affect the performance of Wing Amerta Installation staff at Sanglah Hospital Denpasar. To improve service to patients in the Amerta Wing based on the background of the problem, the problem can be summarized as follows: 1) How does the influence of competence on employee motivation in the Amerta Wing RSUP Sanglah, Denpasar? 2) what is the effect of leadership on employee motivation at the Wing Amerta Installation in RSUP Sanglah Denpasar? 3) how is the influence of competence on employee performance in the Wing Amerta Installation of 
RSUP Sanglah Denpasar? 4) what is the effect of leadership on employee performance at the Wing Amerta Installation at RSUP Sanglah Denpasar? 5) how is the influence of motivation on employee performance at the Wing Amerta Installation in RSUP Sanglah Denpasar? 6) What is the role of motivation in mediating the effect of competence on employee performance? 7) what is the role of motivation in mediating the influence of leadership on employee performance? Competence literally comes from the word competence, which means ability, authority and ability. In terms of etymology, competence means aspects of excellence, expertise from the behavior of an employee or leader who has a good knowledge, behavior and skills. Characteristics of competencies are things that are part of personal character and become part of one's behavior in carrying out a work task (Mangkunegara, 2007).

\section{CONCEPT AND HYPOTHESIS}

In (McClelland, 2009), motivation is a result of one's interactions with certain situations that are encountered. According to Robbins \& Judge (2013) states the definition of motivation is the willingness to spend a high level of effort for organizational goals that are conditioned by the ability of the effort to meet some individual needs. Indicators of motivation according to Mc, Clellend's describes three types of motivation, which are identified in the book "The Achieving, (achievement motivation), (motivational power), (affiliated motivation).

Leadership is the overall activity in order to influence people to want to work together to achieve a goal that is desired together (Ardana, 2012; Hasibuan, 2016) states that leadership is the way a leader influences the behavior of subordinates, so willing to work together and work productively to achieve organizational goals.

Performance is an abbreviation of work energy or in English called as performance which is performance is the result or output produced by the functions or indicators of a job or a profession within a certain period (Alexandri, Pragiwani, \& Yuswardi, 2019).

Based on the literature review above, it is known that competence and leadership are independent variables, while motivation is a mediating variable and employee performance is the dependent variable. For more details look at the Figure as follows.

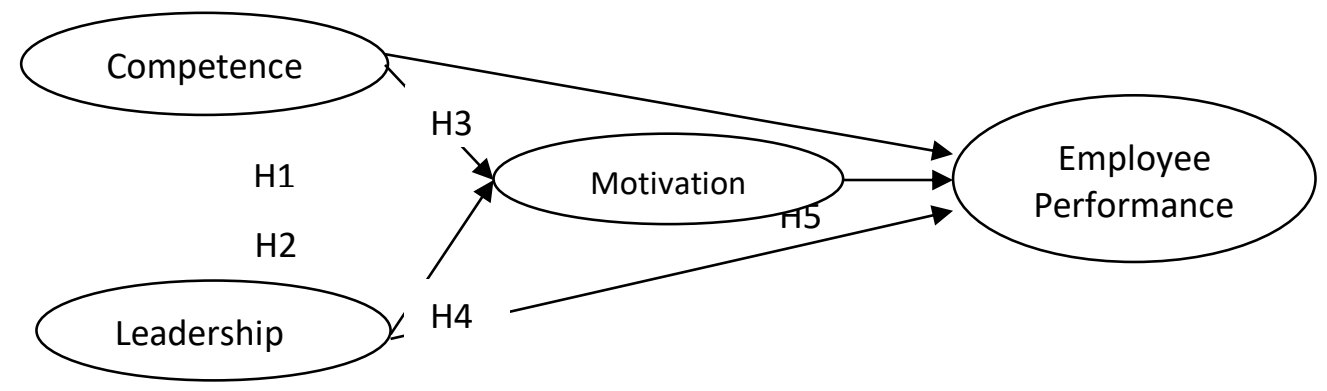

Figure 1. Conseptual Research Framework

\section{Variable Operational Definition}

The operational definition of a variable aims to provide guidance on the implementation of the measurement of a variable, this definition is based on things that can be observed and measured. The operational definition in this research is firstly motivation is a set of attitudes and values that affect paramedics. To obtain maximum results according to the purpose. Which refers to (McClelland, 2009)'s theory and its indicators refer to (Mas'ud, 2004) namely:

a. Motivation in power

b. Achievement motivation

c. Affiliated motivation

Leadership is connected with the process of influencing people to contain understanding as an embodiment of the behavior of a leader regarding his ability to lead. The embodiment usually forms a certain pattern or form. There are 4 (four) indicators adopted 
from situational leadership theory according to (Wirjana \& Supardo, 2005:4)

Employee competence is the ability of an employee to share knowledge and carry out tasks in a skillful manner in accordance with his final education. The employee competencies of Sanglah Hospital employees are measured from aspects below.

a. Formal education is the last level of school pursued by employee

b. Knowledge is the skill of employee has in accordance with his profession, so that his tasks can be carried out properly

c. The level of understanding of the task is the ability to carry out the task appropriately so that it can be more effective and efficient

d. The ability of technical skills possessed by an employee who is able to support the effectiveness and efficiency of work in his department

e. Work discipline includes employee obedience in attendance in accordance with predetermined working hours and hours

Performance is the degree of compilation of tasks that govern one's work. so as performance is the willingness of a person or group to carry out activities or perfect them according to their responsibilities with the results as expected. According to (Mathis \& Jackson, 2006) the indicators in measuring employee performance or achievement are as follows.

a. Work quantity is the number of patients receiving services under normal conditions.

b. Quality of work is the form of neatness of accuracy and relevance of results without ignoring the volume of work.

c. The use of time is the use of work tenure which is adjusted to the policy of the company or government agency.

d. Cooperation is the ability to handle relationships with others at work.

e. Quality of service in serving customers

\section{METHOD}

This study was designed in qualitative research and was conducted at the Wing Amerta Installation Sanglah Denpasar Hospital, the respondents are all 50 outpatient personnel, the data collected related to competence, leadership, motivation and performance. The data was analysed by using PLS (Partial Least Square) (Jogiyanto \& Abdillah, 2009). After analysing the data, then presenting in a formal thecnique.

\section{RESULT AND DISCUSSION \\ The Influence of Competence on Employee Work Motivation in the Amerta Wing RSUP Sanglah Denpasar}

Based on testing results about the effect of competence on motivation, shows competence has a positive and significant effect on work motivation. These results give the meaning that the more competent employees have, the motivation to work at the Wing Amerta installation staff in RSUP Sanglah Denpasar increases significantly. A competence has a positive effect on motivation and the relationship is significant with. In terms of competency indicators, there are 2 indicators whose scores are above average, namely service (very good) and ability to cooperate (very good). Thus the hypothesis in this study which states that competence has a positive and significant effect on work motivation of Wing Amerta RSUP Sanglah Denpasar staff is proven.

Employee competency is a characteristic that is owned by each individual to meet certain criteria or positions. The more competent an employee is, the more responsible and professional they are to produce better performance. To develop these competencies, employees must have a good attitude towards their profession. This is reinforced by the opinion of (Walgito, 2003) that a professional conducts his work in accordance with the demands of the profession. The results of this study are also in line with research conducted by research

\section{The Influence of Leadership on Employee Work Motivation on the Amerta Wing RSUP Hospital Denpasar}

Based on the results of testing on the influence of leadership on work motivation, it shows that leadership has a positive influence on motivation and the relationship is not 
significant. That is, better leadership will affect employee work motivation in carrying out tasks serving patients in the Amera Wing RSUP Sanglah Denpasar in terms of leadership indicators, there are 2 indicators whose scores are above average, they are delegating and paticipacing indicators, so leadership in the Amerta Wing RSUP Sanglah Denpasar delegation of tasks has been running optimally and leadership participation becomes motivation in providing services to patients.

The results of this analysis revealed by (Ardana, 2012; Hasibuan, 2016) leadership is the overall activity in order to influence people to want to work together to achieve a goal that is desired together with different research results with the same variables conducted by (Rantesalu, Mus, Mapparenta, \& Arifin, 2016; Khattak, Mustafa, Rehman, \& Khattak, 2016) which shows that leadership has a positive and significant effect on motivation.

\section{The Influence of Competence on Employee Performance at the Wing Amerta RSUP Sanglah Denpasar}

Based on the results of the test regarding the effect of competence on employee performance, positively positive competence is equal to performance, and the relationship is significant with value. This results gives the meaning that competence is very important in improving performance, the higher the competency of a person, the more competent in carrying out their duties and the assignment of someone according to their competence will affect performance, Thus the hypothesis in this study states that competence has a positive and significant effect on employee performance. The results of this study are in line with the (Yuliantini, Astika, \& Badera, 2017; Alexandri, Pragiwani, \& Yuswardi, 2019; Khoreva, Vaiman, \& Zalk, 2017) who found competence to have a significant effect on employee performance

The Effect of Leadership on Employee Performance in the Wing Amerta Installation of RSUP Sanglah Denpasar

Based on the results of testing on the influence of leadership on employee performance shows that leadership has a negative effect on performance, and the relationship is not significant on performance. Different results found by (Ginantra, 2017), leadership has a positive influence on employee performance.

\section{Effect of Motivation on Employee Performance in the Wing Amerta Installation of RSUP Sanglah Denpasar}

Based on the results of testing on the effect of motivation on performance shows that motivation has a positive effect on performance and the relationship is significant. In terms of motivation indicators, almost all motivational indicators with scores above average. Thus the hypothesis in this study which states that motivation has a positive and significant effect on employee performance in the Wing Amerta Installation. The results of this study are in line with (Biru, Utami, \& Mayowan, 2016; Kardiasih et al., 2017) who find motivation significantly has a positive influence on performance.

The Role of Motivation in Mediating the Effect of Competence on employee performance in the Wing Amerta Installation of Sanglah Hospital Denpasar

Based on the results of calculations and statistical tests, motivation is a partial mediation between competence on performance, because the coefficient of the indirect relationship of competence to performance is smaller than the direct relationship coefficient, and all relationships, both direct and indirect, are significant.

Research with the same results found by (Fauzan \& Sumiyati, 2015), in his research found motivation has a positive and significant effect on performance and motivation has a significant effect on employee performance meaning that both directly and mediating motivation, competence has a significant effect on performance and motivation plays a role in mediating the effect of competence on performance, different results found by (Rantesalu et al., 2016), competence did not significantly influence performance at PT X Surabaya, while (Dharmanegara et al., 2016; Kardiasih et al., 2017), which stated the analysis of the mediating role of work motivation on the relationship between competence on employee 
performance found that work motivation is a partial mediating variable

\section{The Role of Motivation in Mediating the Effects of Leadership on employee performance in the WingAmerta Installation of RSUP Sanglah Denpasar}

Based on the results of direct and indirect analysis of motivation is a perfect mediation between leadership and performance, because indirect relationships are significant and direct relationships are not significant. Research with different results revealed by (Mee, Ismail, Mohamad, Ibrahim, \& Abaeian, 2018; Goel, Sahai, Vinaik, \& Garg, 2019, Saputri \& Muhsin, 2018) which found leadership has a significant effect on employee performance, leadership variable has a positive and significant effect on employee performance

\section{CONCLUSION}

As for some conclusions that can be raised from the results of the description and analysis results of direct and indirect. 1) Competence has a positive and significant influence on motivation among employees of the Wing Amerta Installation at RSUP Sanglah Denpasar. These results give the meaning that the higher the competence, the motivation will increase. 2) Leadership has a positive and significant influence on employee motivation in the Wing Amerta Installation of Sanglah Hospital Denpasar. This result give the meaning that leadership plays an important role in motivating employees of the Wing Amerta Installation at Sanglah Hospital Denpasar. 3) Motivation has a positive and significant effect on the performance of Wing Amerta Installation staff at RSUP Sanglah Denpasar. This result means that motivation has a role in improving employee performance at the Wing Amerta Installation of Sanglah Hospital Denpasar. 4). Competence has a positive and significant effect on employee performance in the Wing Amerta Installation of RSUP Sanglah Denpasar. These results mean that the higher the competency, the performance of employees at the Sanglah Wing Hospital in Denpasar is increasing significantly. 5) Leadership has a negative influence on employee performance in the Wing Amerta Installation of RSUP Sanglah
Denpasar. This result gives the meaning that the parade in Wing Amerta does not wait for direction from the leadership in carrying out tasks. 6) Motivation is a partial mediation between competencies and employee performance in the Wing Amerta Installation of RSUP Sanglah Denpasar. This means that motivation mediation contributes less in improving performance than without mediation. able to mediate the competence of employee performance in the Wing Amerta Installation of RSUP Sanglah Denpasar, with mediating motivation, it makes a major contribution in improving performance. 7) Motivation is a full mediation between leadership and employee performance at the Wing Amerta Installation of Sanglah Hospital Denpasar. With mediation motivation provides the main contribution in improving employee performance.

\section{REFERENCES}

Alexandri, M. B., Pragiwani, M., \& Yuswardi. (2019). The Effect of Competence and Discipline of Work on Motivation and Its Impact on Performance of Forensic Checkers at Puslabfor Bareskrim Indonesia National Police (POLRI). Academy of Strategic Management Journal, 18(4), 1-13.

Ardana. (2012). Manajemen Sumber Daya Manusia. Yogyakarta: Graha Ilmu.

Biru, M., Utami, H. N., \& Mayowan, Y. (2016). Analisis Faktor-Faktor Stres Kerja yang Mempengaruhi Kinerja Karyawan (Studi pada Karyawan Tetap PG. Kebon Agung Kabupaten Malang). Jurnal Administrasi Bisnis (JAB), 39(2), 50-56.

Dharmanegara, I. B. A., Sitiari, N. W., \& Wirayudha, I. D. G. N. (2016). Job Competency and Work Environment: the effect on Job Satisfaction and Job Performance among SMEs Worker. IOSR Journal of Business and Management (IOSRJBM), 18(1), 19-26.

Fauzan, A. H., \& Sumiyati. (2015). Kinerja Karyawan (Studi pada Karyawan PT . Bank Mandiri Tbk. Area Cirebon (Yos Sudarso). Universitas Pendidikan Indonesia.

Ginantra, I. P. G. (2017). Pengaruh Kepemimpinan, Motivasi dan Kepuasan Kerja terhadap Kinerja Karyawan PT Jasamarga Bali Tol di Denpasar. JAGADHITA:Jurnal Ekonomi \& Bisnis, 4(2), 101-115.

Goel, R., Sahai, S., Vinaik, A., \& Garg, V. (2019). Moving from cash to cashless economy: A 
study of consumer perception towards digital transactions. International Journal of Recent Technology and Engineering, 8(1), 12201226.

Hasibuan, H. M. S. (2016). Manajemen Sumber Daya Manusia Edisi Revisi (Cetakan ke). Jakarta: Bumi Aksara.

Jogiyanto, \& Abdillah, W. (2009). Konsep dan Aplikasi PLS (Partial Least Square) untuk Penelitian Empiris. Yogyakarta: BPFE.

Kardiasih, K., Yasa, S., \& Sitiari, W. (2017). Pengaruh motivasi dan lingkungan kerja fisik terhadap kepuasan kerja dan kinerja pegawai pada dinas kebudayaan kota denpasar. Jurnal Ekonomi \& Bisnis JAGADITHA, 4(2), 55-62.

Khattak, M. S., Mustafa, U., Rehman, A. U., \& Khattak, I. U. (2016). Impact of Management Competencies and Complexities on Performance in Public Sector Infrastructure Projects of Pakistan. NUML International Journal of Business \& Management, 11(2), 12-34.

Khoreva, V., Vaiman, V., \& Zalk, M. Van. (2017). Talent Management Practice Effectiveness: Investigating Employee Perspective. Employee Relations: The International Journal, 39(1), 19-33.

Mangkunegara, A. P. (2007). Manajemen Sumber Daya Manusia (7th ed.). Bandung: PT Remaja Rosdakary.

Mas’ud, F. (2004). Survai Diagnosis Organisasional. Semarang: Badan Penerbit Universitas Diponegoro.

Mathis, R. L., \& Jackson, J. H. (2006). Human Resource Management: Manajemen Sumber Daya Manusia. Jakarta: Salemba Empat.

McClelland, D. C. (2009). Entrepreneur Behavior and Characteristics of Entrepreneurs. The Achieving Society.

Mee, L. Y., Ismail, N., Mohamad, F., Ibrahim, A. B., \& Abaeian, V. (2018). Competency Gap and Coping Strategies of Academic Leaders at Higher Education Institutions in Malaysia. TAYLOR'S Business Review A Contemporary Business Journal, 7(1), 41-62.
Rai, I. A. A., \& Purnawati, N. K. (2017). Faktor Faktor yang Mempengaruhi Kredit pada Bank Umum Swasta Nasional (Busn) Devisa. E-Jurnal Manajemen Universitas Udayana, 6(11), 255313.

Rantesalu, A., Mus, A. R., Mapparenta, \& Arifin, Z. (2016). The Effect of Competence , Motivation and Organizational Culture on Employee Performance : the Mediating Role of Organizational Commitment. Quest Journals: Journal of Research in Business and Management, 4(9), 8-14.

Rivai, V. (2013). Manajemen Sumber Daya Manusia Untuk Perusahaan. Jakarta: PT Raja Grafindo Persada.

Robbins, S. P., \& Judge, T. A. (2013). Organizational Behavior (15th ed.). Boston: Pearson Education, Inc.

Saputri, E. D., \& Muhsin. (2018). Peran Komitmen Organisasi Dalam Memediasi Pengaruh Variabel Keteladanan Pemimpin, Kompetensi Perangkat Desa, Dan Budaya Organisasi Terhadap Kinerja. Economic Education Analysis Journal, 7(3), 11301147.

Tarandung, C. D. . (2016). the Impact of Motivation, Participation and Competence of Employee Performance in Food Security and Agricultural Extension Office of East Bolaang Mongondow District. Jurnal Berkala Ilmiah Efisiensi, 16(2), 550-559.

Walgito, B. (2003). Pengantar psikologi umum. Yogjakarta: Andi.

Wirjana, B. R., \& Supardo, S. (2005). Kepemimpinan, Dasar-Dasar dan Pengembangannya. Yogyakarta: CV. Andi offset.

Yuliantini, P. A., Astika, I. B. P., \& Badera, D. N. (2017). Pengaruh Kompetensi Sumber Daya Manusia, Motivasi Dan Lingkungan Kerja Pada Komitmen Organisasi Dan Implikasinya Pada Kinerja Pengurus Barang. E-Jurnal Ekonomi Dan Bisnis Universitas Udayana, 6(10), 3697-3730. 